\title{
THE ROLE OF SELF-INCOMPATIBILITY AND SEXUAL SELECTION IN THE GYMNOSPERM-ANGIOSPERM TRANSITION: A HYPOTHESIS
}

\author{
Michael S. Zavada and Thomas N. Taylor \\ Department of Botany, University of the Witwatersrand, 1 Jan Smuts Avenue, Johannesburg, 2001, \\ Republic of South Africa; Department of Botany, Ohio State University, 1735 Neil Avenue, \\ Columbus, Ohio 43210 \\ Submitted March 15, 1985; Revised July 30, 1985; Accepted January 8, 1986
}

In recent years increased attention has been directed to the general area of plant reproductive biology and in particular to the mechanism and significance of incompatibility in the origin and subsequent evolution of flowering plants. To date almost all research in this area has focused on extant plants in an attempt to characterize evolutionary relationships among the diverse angiosperm reproductive systems. Despite an extensive body of neontological data on plant reproductive biology, there has been little attempt to use these data to interpret the fossil record.

The origin of intraspecific self-incompatibility (SI) is regarded as a significant event in the evolution of flowering plants (Whitehouse 1950). There are no documented cases of SI in gymnosperms. Extant plants with sporophytic selfincompatibility (SSI) have pollen with reticulate exine sculpturing (Zavada $1984 a$ ). In this system the reticulum is believed to form a repository for tapetal substances that operate in the SI system (Heslop-Harrison et al. 1973; Dickinson and Lewis 1975; Heslop-Harrison 1975). On the basis of the sculptural pattern of pollen, it has been suggested that many of the early Cretaceous angiosperms possessed SSI (Zavada 1984a). Gametophytic self-incompatibility (GSI) depends primarily on interaction between the pollen tube and style; current fossil evidence suggests that the style did not evolve until the upper Lower Cretaceous or lower Upper Cretaceous (Dilcher 1979; Krassilov 1982), postdating the occurrence of many pollen types indicative of the SSI system. This is troubling because SSI is generally considered derived from GSI, which the present fossil evidence does not suggest.

Self-incompatibility has traditionally been viewed as a mechanism to promote outbreeding (deNettencourt 1977); however, outbreeding can be accomplished in gymnosperms and angiosperms in other ways (e.g., protandry). In addition, recent data suggest that dioecy can be a more efficient mechanism for achieving outbreeding than SI (Anderson and Stebbins 1984). It has also recently been hypothesized that SI is a mechanism by which the female can assess male quality before fertilization (Willson and Burley 1983). This implies that SI permits accep- 
characteristics of the SSI system gave rise to GSI and SSI (e.g., Theobroma; Knight and Rogers 1953, 1955).

Theobroma cacao L. (Sterculiaceae) has an unusual type of incompatibility that may bear on the last possibility suggested above. After pollination in Theobroma, the pollen tube emerges from the hollow style and grows into the embryo sac. The pollen tube will grow at the same rate in an incompatible or a compatible combination. When the pollen tube contacts the ovules, an incompatible reaction results in non-fusion of the gametophytic nuclei. A compatible combination is followed by fusion of the nuclei (Posnette 1940; Cope 1962a,b). Regardless of the number of compatible pollen tubes in a single flower, a single incompatible combination results in flower abortion (Knight and Rogers 1955; Cope 1962a,b). It has been suggested that in Theobroma, flower abscission is initiated after the pollen tube and ovules have come into contact (Cope 1962a,b). However, assessment (recognition) can take place in two localities in this situation, the stigma or pollen tubeovule interface. The morphology of Theobroma pollen is consistent with the morphology of pollen from plants with SSI (Zavada 1984a), which generally have stigmatic recognition. This raises the possibility that recognition in Theobroma is a stigmatic phenomenon and that floral abscission is initiated by events on the stigma (entirely under sporophytic control as suggested in Knight and Rogers 1955; Glendinning 1960, 1967; Arevalo et al. 1972; Jacob and Atanda 1975; Frankel and Galun 1977, p. 184; Terreros et al. 1982). The events that subsequently occur between the ovule and pollen tube, although reflecting genetic aspects of the gametes, may be incidental to the recognition (stigmatic)-rejection (abortion of the flower) reaction. In addition, the stigma and style are known to be sensory organs for the flower, and the initiation of abscission and of fruit development are controlled by events that occur in these organs (Linskens 1974; Wiemken-Gehrig et al. 1974; Gilissen 1976; Goldschmidt 1980; Reid et al. 1984). Thus, Theobroma might be an example of an SI system in which recognition (assessment) is stigmatic (prezygotic) and inhibition (rejection) results in abortion of the flower. If the Theobroma type of SI is considered primitive (Knight and Rogers 1953, 1955), an evolutionary refinement of this system would be pollen-tube inhibition (found in most GSI and SSI plants). The evolutionary development of pollen-tube inhibition has energetic advantages over the Theobroma type; entire flowers need not be sacrificed because of an incompatible pollination.

It is also interesting to note that the reproductive biology of the primitive taxa Pseudowintera (Godley and Smith 1981), Illicium (Thien et al. 1983), and Austrobaileya (Prakash and Alexander 1984; Zavada, unpubl. data) is similar to that postulated for Theobroma. All these taxa lack styles, possess pollen morphology similar to plants with SSI, and commonly abort flowers.

\section{MATE CHOICE: FOSSIL GYMNOSPERMS AND ANGIOSPERMS}

The ovule-bearing reproductive organs of the early Mesozoic gymnosperm and the early Cretaceous angiosperm have a number of features in common. Many of the early Mesozoic gymnosperms (pteridosperms) consist of ovule-bearing parts that are morphologically spikes or racemes. The individual ovule-bearing parts are 
many gymnosperm pollen grains are thought to aid in dispersal, serve as a structure to accommodate volumetric changes resulting from water relations of the pollen grain (harmomegathy; Chaloner 1976), or orient the grain with the germinal aperture toward the nucellus (Doyle 1945; however, see McWilliam 1958). The sacci, however, appreciably increase the size of a pollen grain (by $50 \%$ in most taxa; Zavada, unpubl. data) without increasing the male investment, because the cytoplasm is confined to the corpus of the grain. Perhaps the most significant function of the sacci in this morphological grain type is to physically exclude contemporary males from the limited nucellar space. Thus, polyspermy and saccate pollen may be mechanisms by which a single male can reduce competition with other males and thus increase its chances of acceptance by the female.

Mate choice in gymnosperms (in the sense of Willson and Burley 1983) has two components: postzygotic assessment of the male by the female and the rejection of unfit zygotes by abortion. The timing of assessment in gymnosperms permits a number of male mechanisms to reduce competition among males, ultimately reducing the array of genetically heterogeneous males from which the female chooses and thus influencing the effectiveness of polyembryony as an assessment mechanism. Abortion may also include the reallocation of retrievable resources that were initially invested in zygotes destined for abortion (as in some angiosperms; Wiemken-Gehrig et al. 1974; Gilissen 1976; Goldschmidt 1980).

In angiosperms SI can be separated into two components: recognition (assessment and choice as defined in Willson and Burley 1983) and inhibition (rejection). Two types of SI systems vary with the site of recognition and inhibition. Recognition and inhibition in the gametophytic type occur in the style, except in a few cases when they occur on the stigma (e.g., Oenothera, some grasses). In the sporophytic type, recognition and inhibition generally occur on the stigma. In both instances recognition and inhibition of the pollen tube are prezygotic and occur either on the stigma or in the style.

On the basis of neontological data it is believed that GSI is phylogenetically primitive, whereas SSI is derived (Whitehouse 1950; Brewbaker 1957, 1959; Pandy 1958, 1960, 1980; Crowe 1964). The early occurrence of SSI proposed on the basis of fossil data (Zavada 1984a), however, suggests alternative interpretations of the phylogenetic relationships of GSI and SSI. One of these interpretations states that GSI was present before the proposed Lower Cretaceous origin of SSI. Several pollen types that appeared before and at the same time as the first angiosperm pollen indicative of SSI plants are similar to pollen from plants with GSI (however, many gymnosperms and angiosperms without SI also have this pollen type; Zavada 1984a). In addition, some GSI plants possess stigmatic recognition. If stigmatic recognition occurred in the earliest GSI plants, the discrepancy between the time of origin of the style and the earlier origin of SSI can be resolved on the basis of existing data (i.e., the gametophytic type is primitive and the sporophytic type is derived). Another explanation is that SSI is primitive and GSI is derived. It is interesting that the morphology of the earliest known angiosperm pollen and the subsequent appearance of the style support this suggestion. Finally, the possibility cannot be ruled out that some other SI system with 
characteristics of the SSI system gave rise to GSI and SSI (e.g., Theobroma; Knight and Rogers 1953, 1955).

Theobroma cacao L. (Sterculiaceae) has an unusual type of incompatibility that may bear on the last possibility suggested above. After pollination in Theobroma, the pollen tube emerges from the hollow style and grows into the embryo sac. The pollen tube will grow at the same rate in an incompatible or a compatible combination. When the pollen tube contacts the ovules, an incompatible reaction results in non-fusion of the gametophytic nuclei. A compatible combination is followed by fusion of the nuclei (Posnette 1940; Cope 1962a,b). Regardless of the number of compatible pollen tubes in a single flower, a single incompatible combination results in flower abortion (Knight and Rogers 1955; Cope 1962a,b). It has been suggested that in Theobroma, flower abscission is initiated after the pollen tube and ovules have come into contact (Cope 1962a,b). However, assessment (recognition) can take place in two localities in this situation, the stigma or pollen tubeovule interface. The morphology of Theobroma pollen is consistent with the morphology of pollen from plants with SSI (Zavada 1984a), which generally have stigmatic recognition. This raises the possibility that recognition in Theobroma is a stigmatic phenomenon and that floral abscission is initiated by events on the stigma (entirely under sporophytic control as suggested in Knight and Rogers 1955; Glendinning 1960, 1967; Arevalo et al. 1972; Jacob and Atanda 1975; Frankel and Galun 1977, p. 184; Terreros et al. 1982). The events that subsequently occur between the ovule and pollen tube, although reflecting genetic aspects of the gametes, may be incidental to the recognition (stigmatic)-rejection (abortion of the flower) reaction. In addition, the stigma and style are known to be sensory organs for the flower, and the initiation of abscission and of fruit development are controlled by events that occur in these organs (Linskens 1974; Wiemken-Gehrig et al. 1974; Gilissen 1976; Goldschmidt 1980; Reid et al. 1984). Thus, Theobroma might be an example of an SI system in which recognition (assessment) is stigmatic (prezygotic) and inhibition (rejection) results in abortion of the flower. If the Theobroma type of SI is considered primitive (Knight and Rogers 1953, 1955), an evolutionary refinement of this system would be pollen-tube inhibition (found in most GSI and SSI plants). The evolutionary development of pollen-tube inhibition has energetic advantages over the Theobroma type; entire flowers need not be sacrificed because of an incompatible pollination.

It is also interesting to note that the reproductive biology of the primitive taxa Pseudowintera (Godley and Smith 1981), Illicium (Thien et al. 1983), and Austrobaileya (Prakash and Alexander 1984; Zavada, unpubl. data) is similar to that postulated for Theobroma. All these taxa lack styles, possess pollen morphology similar to plants with SSI, and commonly abort flowers.

\section{MATE CHOICE: FOSSIL GYMNOSPERMS AND ANGIOSPERMS}

The ovule-bearing reproductive organs of the early Mesozoic gymnosperm and the early Cretaceous angiosperm have a number of features in common. Many of the early Mesozoic gymnosperms (pteridosperms) consist of ovule-bearing parts that are morphologically spikes or racemes. The individual ovule-bearing parts are 
cupulate structures (e.g., fig. 1A) containing one to five ovules per cupule (table 1). The number of these compact structures that are borne on a particular plant is unknown and may well be irrelevant. The earliest known angiosperm inflorescences are likewise compact structures containing 25 to 2500 or more carpellate units (each carpellate unit is analogous to the cupulate structure of the gymnosperms mentioned above), each with fewer than 10 ovules. In both of these groups the ovule-producing units are of one sex and are generally lacking accessory floral parts (fig. 1, table 1).

Regardless of the precise group that gave rise to the angiosperms and the homology that may exist with reference to the ovule-bearing organs, the similarity between early angiosperm reproductive structures and Mesozoic gymnosperms (pteridosperms) suggests that similar selective pressures influenced their morphology (although this similarity may reflect a common ancestry). The morphological shift from the Mesozoic pteridosperm structure to the earliest angiosperm type required the enclosure of the ovules. Both groups possess a similar type of inflorescence, a similar arrangement of ovule-bearing units, and a general lack of accessory structures (fig. 1, table 1).

The shift from postzygotic to prezygotic mate assessment (SI) in the female (i.e., gymnospermous to angiospermous condition) necessitates the concomitant evolutionary development of sterile sporophytic tissue between the ovules and the male gametes (i.e., stigma and carpel). In fact, Whitehouse (1950) suggested that the evolutionary development of the stigma, style, and carpel may be more a response to the evolutionary development of SI in angiosperms than a means of protecting the ovules. Phytophagy has been invoked as the selective pressure that brought about the closed carpel (e.g., Stewart 1983, and references therein). However, phytophagous insects with chewing or sucking mouthparts are known from the Carboniferous, and almost all the major phytophagous groups were present by the Triassic (Rohdendorf and Raznitsin 1980; Strong et al. 1984). If protection is the major selective impetus for the closed carpel, it would follow that the origin of the carpel is more closely correlated with the time of appearance of major phytophagous-insect groups. We can find no data that support a correlation between the first appearance of major phytophagous-insect groups and the origin of the carpel. It is our contention that the evolutionary development of prezygotic mate assessment (SI) was accompanied by the interpolation of sterile tissue (i.e.. functional stigmatic surface) between the ovules and the male gametes (the plesiomorphic condition as determined by neontological and fossil data; Bailey and Swamy 1951; Dilcher 1979; Dilcher and Crane 1984).

Investigators have proposed that GSI is primitive in angiosperms and that SSI is derived. However, neontological and fossil data relevant to the evolutionary relationships of carpel characteristics make GSI an unlikely candidate for the primitive type (Bailey and Swamy 1951). The morphology of the earliest angiosperm pollen, which predates the first occurrence of the style in the fossil record. conforms to the pollen morphology found in plants with SSI (stigmatic recognition and inhibition). In addition, neontological data suggest that the style is a derived feature in angiosperms. The plesiomorphic condition is considered a conduplicate carpel with an ill-defined stigmatic area and no style (Bailey and Swamy 1951). 

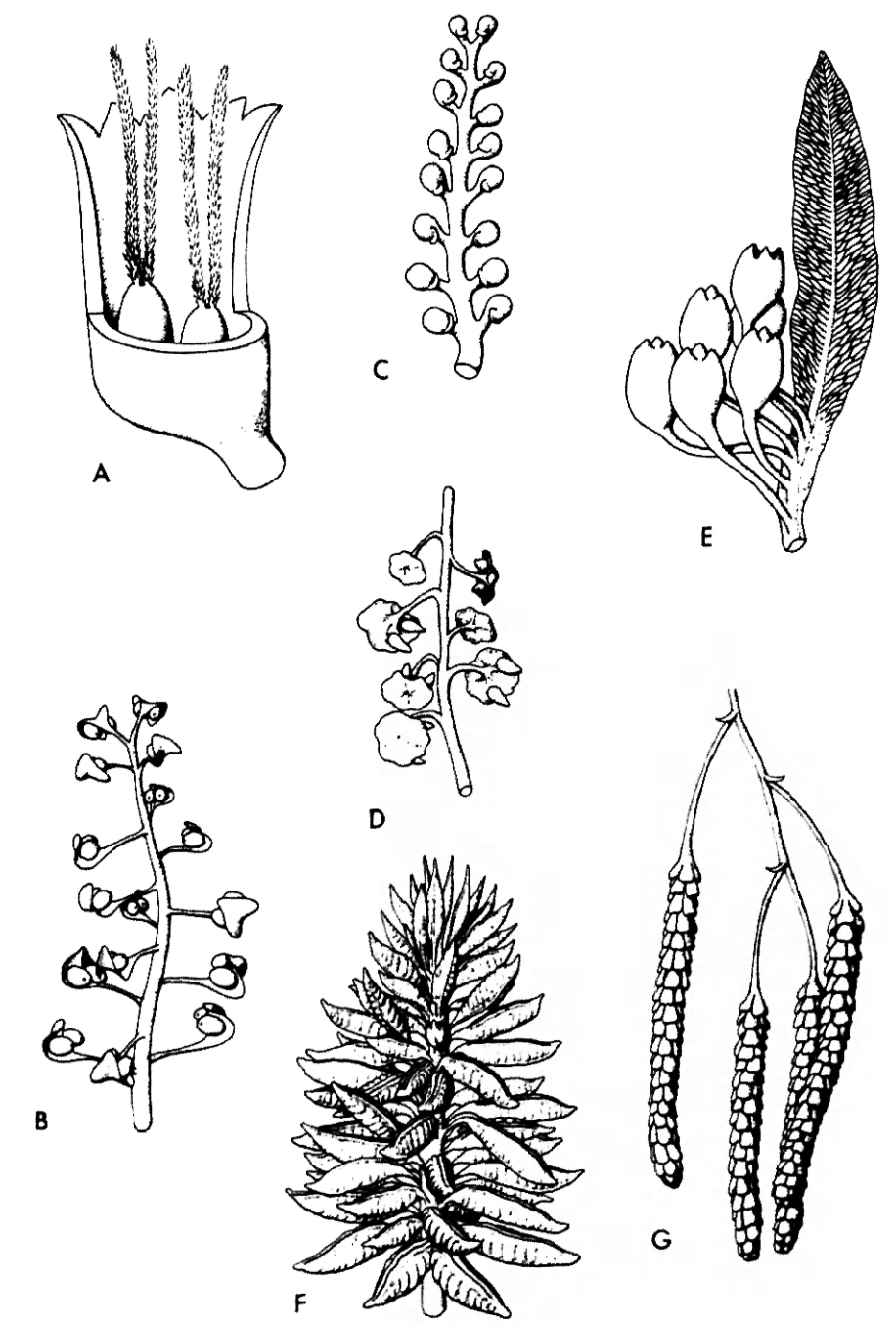

Fig. 1.-Representative Paleozoic $(A)$ and Mesozoic $(B-G)$ reproductive organs illustrating the morphological similarity between fossil pteridosperms $(A-E)$ and early angiosperms $(F, G)$ fructifications. A, Pteridospermous cupule of Gnetopsis elliptica containing two ovules, each with extended micropylar plumes. The arrangement and number of these structures on a single plant is unknown. A portion of the cupule has been cut away to reveal the ovules. Redrawn from Millay and Taylor 1978. B, Cycadalean ovulate cone, Beania gracilis. Redrawn from Harris 1941. C, Ovule-bearing megasporophyll of the pteridosperm Caytonia nathorsti. Redrawn from Thomas 1925. D, Ovule-bearing cupulate discs of the peltasperm Lepidopteris sp. Redrawn from Thomas 1955. E, Ovule-bearing organ of the glossopterid pteridosperm Lidgettonia mucronata. Redrawn from Surange and Chandra 1975. $F$, Multicarpellate organ of the early angiosperm Archaeanthus. Redrawn from Dilcher 1979. G, Multicarpellate organs of Prisca reynoldsii. Redrawn from Retallack and Dilcher 1981. 
TABLE 1

Characteristics of Some Important Mesozoic Pteridosperms, Early Angiosperms, and Extant Angiosperms

\begin{tabular}{|c|c|c|c|c|c|c|}
\hline $\begin{array}{c}\text { Plant } \\
\text { (Source) }\end{array}$ & Perianth & $\begin{array}{l}\text { Unisexual } \\
\text { Inflor- } \\
\text { escence }\end{array}$ & $\begin{array}{l}\text { Inflor- } \\
\text { escence } \\
\text { Type }\end{array}$ & $\begin{array}{l}\text { No. Cupules } \\
\text { (Carpels) } \\
\text { per Inflor- } \\
\text { escence }\end{array}$ & $\begin{array}{c}\text { No. Seeds } \\
\text { (Ovules) } \\
\text { per Cupule } \\
\text { (Carpel) }\end{array}$ & Age \\
\hline $\begin{array}{l}\text { Umkomasia; Philopherospermum } \\
\text { (Thomas 1933) }\end{array}$ & - & + & raceme & 10 & $?$ & Triassic \\
\hline $\begin{array}{l}\text { Leptostrobus laxifolia } \\
\quad \text { (Harris 1951) }\end{array}$ & - & + & spike & 10 & $3-5$ & Jurassic \\
\hline $\begin{array}{l}\text { Caytonia spp. } \\
\quad \text { (Harris 1951, 1964) }\end{array}$ & - & + & spike & 15 & 4 & Jurassic \\
\hline $\begin{array}{l}\text { Irania hermaphroditica } \\
\text { (Schweitzer 1977) }\end{array}$ & - & $-*$ & spike & 30 & 4 & Jurassic \\
\hline $\begin{array}{l}\text { Ktalenia (Taylor \& } \\
\text { Archangelsky 1985) }\end{array}$ & - & + & spike & 10 & 2 & $\begin{array}{c}\text { Late } \\
\text { Cretaceous }\end{array}$ \\
\hline $\begin{array}{l}\text { Lesqueria } \\
\quad \text { (Crane \& Dilcher 1984) }\end{array}$ & - & + & spike & 50 & $10(?)$ & Cretaceous \\
\hline $\begin{array}{l}\text { Prisca reynoldsii } \\
\quad \text { (Retallack \& Dilcher 1981) }\end{array}$ & - & + & spike & 25 & 5 & Cretaceous \\
\hline $\begin{array}{l}\text { Archaeanthus sp. } \\
\text { (Dilcher \& Crane 1984) }\end{array}$ & $-\dagger$ & $-\dagger$ & spike & 40 & 7 & Cretaceous \\
\hline $\begin{array}{l}\text { Unnamed } \\
\text { (Dilcher 1979, fig. 48; } \\
\text { Kovach \& Dilcher 1983) }\end{array}$ & - & + & spike & 2500 & $1-3$ & Cretaceous \\
\hline $\begin{array}{l}\text { Angiosperms with GSI and SSI } \\
\text { (East 1940; } \\
\text { Cronquist 1981) }\end{array}$ & + & \pm & variable & $\begin{array}{c}2.4 \\
\text { (range, } 1-6)\end{array}$ & $1-\infty$ & Extant \\
\hline
\end{tabular}

NoTE. - Nearly all of the fossil taxa lack a perianth, have only one sex, and possess compact inflorescences with numerous ovule-bearing structures, each with few ovules. The closed carpel is the major difference separating fossil pteridosperms and extant gymnosperms from early fossil angiosperms. However, extant angiosperms with gametophytic self-incompatibility (GSI) and sporophytic self-incompatibility (SSI) differ from these in the consistent presence of a perianth, bisexuality, and a low number of carpels. All plants are considered bisexual (monoecious except Archaeanthus, which may be bisexual).

* Male reproductive structures occur on separate branches in a whorl below the female structures, may be functionally bisexual

† No accessory floral structures are found attached, but abscission scars below the carpels may have been stamens and/or a perianth. 
This morphology conforms with the carpel morphology in most of the earliest known female angiosperm inflorescences (fig. 1; Dilcher 1979; Crane and Dilcher 1984; Dilcher and Crane 1984), and it is not appreciably different from the morphology of the female structures in the geologically earlier gymnosperms (Taylor and Archangelsky 1985). In early angiosperms, recognition of compatible pollen could have occurred, either on the stigma or during interaction of the pollen tube and the ovule. The morphology of the earliest angiosperm pollen strongly suggests stigmatic recognition (Zavada 1984a). This is analogous to the situation described earlier for Theobroma.

If the analogy between the Theobroma type of SI and the SI system proposed for early angiosperms is carried one step further, abortion may have been the inhibition (rejection) reaction (although pollen-tube inhibition cannot be ruled out). However, one important difference between extant angiosperms and the earliest fossil angiosperm inflorescences known to date may be the unit aborted following an incompatible combination. Extant angiosperms are polycarpellate with few to many stamens and a well-developed perianth. The earliest known angiosperms possess many carpels, are of one sex, and usually lack a perianth. In extant angiosperms the entire flower is aborted (e.g., in Theobroma, Cope $1962 a, b ;$ Austrobaileya, Prakash and Alexander 1984; Pseudowintera, Godley and Smith 1981). Early fossil angiosperm inflorescences comprised numerous carpels ( 25 to greater than 2500 ). It is difficult to imagine that the entire polycarpellate structure was aborted. Fossil inflorescences of this type are found where individual carpels have abscised (Kovach and Dilcher 1983; Kovach, pers. comm.). It might be that an incompatible combination resulted in the abortion of single carpels.

The abortion of the entire flower in extant angiosperms and the possibility of abortion of individual carpels in fossil angiosperms raise some interesting questions regarding the homologies of the fossil polycarpellate inflorescences and the flowers of some extant angiosperms (e.g., Theobroma, Austrobaileya). Although speculation about the homologies that may exist between fossil and extant angiosperm inflorescences is beyond the scope of this paper, we assume that many extant angiosperms may have plesiomorphic features (e.g., the SI system in Theobroma) that provide insight into interpreting the fossil record. Nonetheless, extant angiosperms exhibit a number of synapomorphies (not shared by their fossil ancestors) that are a result of millions of years of evolution.

The development of SI permits prezygotic mate assessment and eliminates male mechanisms that affect mate choice (i.e., mechanisms that reduce male competition, including polyspermy). Polyspermy does not occur in angiosperms and was probably lost in the gymnosperm-angiosperm transition. Moreover, the investment in resources necessary to develop zygotes (that will ultimately be aborted) for mate assessment in gymnosperms is not necessary in angiosperms because of the timing of assessment (i.e., prezygotic). The partitioning of one to a few ovules per carpel and of numerous carpels in a large compact inflorescence (the common situation observed in the earliest angiosperms) have certain advantages. This morphology increases stigmatic surface area, thus increasing the opportunity for a successful pollination. This is especially true in the absence of faithful pollinators 
(e.g., bees, which are not known in the fossil record until the Paleocene; Raznitsin 1980) and accessory floral parts (petals) that influence insect behavior (table 1; early Cretaceous angiosperms generally lacked accessory floral parts). The increased stigmatic area also eliminates the effectiveness of sacci for reducing male competition. Virtually no extant angiosperm pollen grains are known to have sacci like those in gymnosperms. (However, pollen of the extant primitive angiosperm Lactoris has small sacci; Carlquist 1964; Zavada and Taylor 1986. Although they form in a manner similar to the sacci in gymnosperms, they do not appreciably increase the size of the pollen. It is interesting to note that the saccate Lactoris pollen is shed in tetrads.) Sacci were probably lost in the gymnospermangiosperm transition (Zavada 1984b; Zavada and Crepet 1986). In the context of the morphology of the earliest angiosperm reproductive structures, the rejection reaction may have been the abortion of the individual carpels that received incompatible pollen. The partitioning of a few ovules in small carpels reduces the overall energy cost of an aborted carpel. In addition, a percentage of the resources invested in an aborted carpel may be recovered before abscission (Gilissen 1976; Goldschmidt 1980). Most importantly, the change in the time of assessment in angiosperms disallows a number of male mechanisms that reduce competition between males in gymnosperms.

The negative effect that the change in the timing of assessment in angiosperms has on mechanisms effective for reducing gametophytic competition in gymnosperms places strong selective pressure on the male to develop alternative mechanisms in order to improve its chances of acceptance by the female in angiosperms. The evolutionary development of accessory floral parts in angiosperms and their morphological modification to influence insect behavior for the effective transfer of pollen to a receptive female (i.e., a female that recognizes the pollen as compatible) may be viewed as a male mechanism that affects mate choice. For example, the transfer of pollen en masse from a single male to a receptive female and the development of multiple pollen units (i.e., polyads; permanent tetrads, pollinia) may be analogous to polyspermy in gymnosperms and may have a similar effect on female assessment (Charnov 1979; Willson 1979; Willson and Burley 1983). In addition, resource investment in accessory reproductive structures (petals) may be attributed to the male. If male reproductive success is limited by the number of females (with a diminishing fitness-gain curve) and female reproductive success is limited by resources (with a linear fitness gain) in a bisexual plant (as assumed here), only the male may shunt resources into the development of accessory floral parts (cf. Charnov 1979, 1982; Willson and Burley 1983). The morphological and phylogenetic relationship between stamens and petals has long been known (Canright 1952). Thus, the evolutionary development of accessory floral parts and their importance to insect pollination are expected to postdate the appearance of SI in the fossil record. The first occurrence of petaloid angiosperm flowers postdates the first occurrence of pollen with features indicative of SSI by five to ten million years or more.

Self-incompatibility also permits close association of male and female reproductive structures (bisexuality) without reducing the array of males in the population from which the female can choose. This situation, along with accessory floral parts for insect pollination, promotes both the dispersal of pollen to a compatible 
female and the reception of compatible pollen by the female, especially in the presence of constant pollinators (e.g., certain groups of flies, Zavada and Dilcher, MS; bees, Crepet 1983, 1984, and references therein).

A further refinement of the SI system proposed here for early angiosperms is the development of pollen-tube inhibition (as in extant plants with GSI or SSI). Pollen-tube inhibition permits the operation of the SI system (prezygotic mate assessment) without abortion of reproductive structures as a result of an incompatible combination. This reduces the energy investment in the development and maintenance of numerous individual carpels with few ovules, including the percentage of these structures that would ultimately be aborted as the result of an incompatible combination. There might be expected a reduction in the number of carpels, the fusion of carpels, and an increase in the number of ovules per carpel, which are all concomitant with development of pollen-tube inhibition. This is the morphological situation observed in many extant plants with GSI and SSI (table 1).

\section{SUMMARY}

Self-incompatibility is viewed as a mechanism by which the female can evaluate the quality of the male gametophyte. This does not preclude its function as an outbreeding mechanism, but rather expands its role as a means to mediate the quality of the offspring by the female. The early angiosperm self-incompatibility system is envisioned as consisting of stigmatic recognition, with an incompatible combination resulting in carpel abortion.

The morphological transition from the gymnospermous to the angiospermous condition (i.e., the placement of sterile sporophytic tissue between ovules and pollen) occurred concomitantly with a change in the timing of mate assessment (postzygotic to prezygotic). The selective impetus for the evolutionary development of the closed carpel is hypothesized to be the origin of self-incompatibility rather than solely a means of protection. This shift in timing prevents mechanisms that were effective for reducing male competition in gymnosperms and intensifies male competition in angiosperms (Mulcahy 1979, 1981). Thus, strong selective pressure was exerted on the male to develop alternative mechanisms for increasing its chances of acceptance by the female in angiosperms. The evolutionary development of accessory floral parts and the morphological modification of these parts to influence insect behavior might be viewed as male mechanisms to better ensure more-efficient transfer of pollen to a receptive female, thus improving its chances of acceptance by the female (cf. Willson and Burley 1983). The evolution of various insect-pollination syndromes, especially those involving faithful pollinators, is considered one of the most important events to have influenced the morphological diversity subsequently observed in angiosperms in the Cretaceous (Crepet 1979, 1983, 1984, and references therein; Mulcahy 1979).

\section{ACKNOWLEDGMENTS}

This research was completed under a grant from the National Science Foundation (BSR 84-02813). 
LITERATURE CITED

Anderson, G. J., and G. L. Stebbins. 1984. Dioecy versus gametophytic self-incompatibility: a test. Am. Nat. 124:423-428.

Arevalo, A., G. A. Carletto, and F. Ocampo. 1972. Determinación de los genotipos de incompatibilidad a compatibilidad en varios clones de cacao. Rev. Theobroma 2:33-38.

Bailey, I. W., and B. G. L. Swamy. 1951. The conduplicate carpel of dicotyledons and its initial trend of specialization. Am. J. Bot. 38:373-379.

Bateman, A. J. 1948. Intrasexual selection in Drosophila. Heredity 2:349-368.

Brewbaker, J. L. 1957. Pollen cytology and self-incompatibility systems in plants. J. Hered. 48: 271-277.

1959. Biology of the angiosperm pollen grain. Indian J. Genet. \& Plant Breed. 19:121-133.

Canright, J. E. 1952. The comparative morphology and relationships of the Magnoliaceae. I. Trends of specialization of the stamens. Am. J. Bot. 39:484-497.

Carlquist, S. 1964. Morphology and relationships of Lactoridaceae. Aliso 5:421-435.

Chaloner, W. G. 1976. The evolution of adaptive features in fossil exines. Linn. Soc. Symp. Ser. 1: $1-14$.

Chamberlain, C. J. 1935. Gymnosperms: structure and evolution. University of Chicago Press, Chicago.

Charnov, E. L. 1979. Simultaneous hermaphroditism and sexual selection. Proc. Natl. Acad. Sci. USA 76:2480-2484.

1982. The theory of sex allocation. Princeton University Press, Princeton, N.J.

Cope, F. W. 1962a. The mechanism of pollen incompatibility in Theobroma cacao L. Heredity 17: 157-182.

$1962 \mathrm{~b}$. The effects of incompatibility and compatibility on genotype proportions in populations of Theobroma cacao L. Heredity 17:183-195.

Crane, P. R., and D. L. Dilcher. 1984. Lesqueria: an early angiosperm fruiting axis from the midCretaceous. Ann. Mo. Bot. Gard. 71:384-402.

Crepet, W. L. 1979. Insect pollination: a paleontological perspective. BioScience 29:102-108.

. 1983. The role of insect pollination in the evolution of the angiosperms. Pages 29-50 in $\mathrm{L}$. Real, ed. Pollination biology. Academic Press, New York.

- 1984. Advanced (constant) insect pollination mechanisms: patterns of evolution and implications vis à vis angiosperm diversity. Ann. Mo. Bot. Gard. 71:607-630.

Croker, T. C. 1964. Fruitfulness of longleaf trees more important than culture in cone yield. J. For. 62:822-823.

Cronquist, A. 1981. An integrated system of classification of flowering plants. Columbia University Press, New York.

Crowe, L. K. 1964. The evolution of out breeding in plants. I. Angiosperms. Heredity 19:435-457.

deNettencourt, D. 1977. Incompatibility in angiosperms. Springer-Verlag, Berlin.

Dickinson, H. G., and D. Lewis. 1975. Interaction between the pollen grain coating and the stigmatic surface during compatible and incompatible interspecific pollinations in Raphanus. Biol. J. Linn. Soc. 7:165-175.

Dilcher, D. L. 1979. Early angiosperm reproduction: an introductory report. Rev. Palaeobot. Palynol. 27:291-328.

Dilcher, D. L., and P. R. Crane. 1984. Archaeanthus: an early angiosperm from the Cenomanian of the western interior of North America. Ann. Mo. Bot. Gard. 71:351-383.

Doyle, J. 1945. Developmental lines in pollination mechanisms in the Coniferales. Sci. Proc. R. Dublin Soc., Ser. A 24:43-62.

East, E. M. 1940. The distribution of self-sterility in the flowering plants. Proc. Am. Philos. Soc. 82:449-518.

Frankel, P., and E. Galun. 1977. Pollination mechanisms, reproduction and plant breeding. Monogr. Theor. Appl. Genet. 2.

Gilissen, L. J. W. 1976. The role of the style as a sense-organ in relation to wilting of the flower. Planta (Berl.) 131:201-202. 
Glendinning, D. R. 1960. Selfing of self-incompatible cocoa. Nature (Lond.) 187:170.

1967. Technical aspects of the breeding programme at the Cocoa Research Institute, Tafo, Ghana. Euphytica 16:76-82.

Godley, E. J., and D. H. Smith. 1981. Breeding systems in New Zealand plants. 5. Pseudowintera colorata (Winteraceae). N.Z. J. Bot. 19:151-156.

Goldschmidt, E. E. 1980. Abscisic acid in citrus flower organs as related to floral development and function. Plant Cell Physiol. 21:193-195.

Grano, C. X. 1957. Indices to potential cone production of loblolly pine. J. For. 55:890-891.

Harris, T. M. 1941. Cones of extinct Cycadales from the Jurassic rocks of Yorkshire. Philos. Trans. R. Soc. Lond. B, Biol. Sci. 231:75-98.

- 1951. The fructification of Czekanowskia and its allies. Philos. Trans. R. Soc. Lond. B, Biol. Sci. 235:483-508.

1964. The Yorkshire Jurassic flora. II. Caytoniales, Cycadales and pteridosperms. British Museum (Natural History), London.

Heslop-Harrison, J. 1975. Incompatibility and pollen-stigma interaction. Annu. Rev. Plant Physiol. 26:403-425.

Heslop-Harrison, J., Y. Heslop-Harrison, R. B. Knox, and B. Howlett. 1973. Pollen wall proteins: "gametophytic" and "sporophytic" fractions in the pollen walls of the Malvaceae. Ann. Bot. 37:403-412.

Jacob, V. J., and O. A. Atunda. 1975. Compatibility and fruit setting in Theobroma cacao L. Rev. Theobroma 5:12-18.

Knight, R., and H. H. Rogers. 1953. Sterility in Theobroma cacao L. Nature (Lond.) 172:164.

1955. Incompatibility in Theobroma cacao L. Heredity 9:69-77.

Kovach, W. L., and D. L. Dilcher. 1983. A new mid-Cretaceous angiosperm fruiting axis. Am. J. Bot. 70:72.

Krassilov, V. A. 1982. Early Cretaceous flora of Mongolia. Palaeontogr. Abt. B, Palaeophytol. 181: $1-43$.

Linskens, H. F. 1974. Translocation phenomena in the petunia flower after cross- and self-pollination. Pages 285-292 in H. F. Linskens, ed. Fertilization of higher plants. North Holland, Amsterdam.

McWilliam, J. R. 1958. The role of the micropyle in the pollination of Pinus. Bot. Gaz. 120:109-117.

Millay, M. A., and T. N. Taylor. 1978. Fertile and sterile frond segments of the lyginopterid seed fern Feraxotheca. Rev. Palaeobot. Palynol. 25:151-162.

Mulcahy, D. L. 1979. The rise of the angiosperms: a genecological factor. Science (Wash., D.C.) 206:20-23.

1981. Rise of the angiosperms. Nat. Hist. 90:30-35.

Pandey, K. K. 1958. On the time of S-gene action. Nature (Lond.) 181:1220.

1960. Evolution of gametophytic and sporophytic systems of self-incompatibility in angiosperms. Evolution 14:98-115.

. 1980. Evolution of incompatibility systems in plants: origin of independent and complementary control of incompatibility in angiosperms. New Phytol. 84:381-400.

Pearson, H. H. W. 1929. Gnetales. Cambridge University Press, Cambridge.

Posnette, A. F. 1940. Self incompatibility in cocoa (Theobroma spp.). Trop. Agric. 17:67-71.

Powell, G. R., K. J. Tosh, and W. R. Remphrey. 1984. Occurrence and distribution of cones borne laterally on long shoots of Larix laricina. Can. J. Bot. 62:771-777.

Prakash, N., and J. H. Alexander. 1984. Self-incompatibility in Austrobaileya scandens. Pages 214 216 in E. G. Williams and R. B. Knox, eds. Proceeding of a symposium, Pollination '84. March 1-2, 1984. Plant Cell Biology Research Centre, School of Botany, University of Melbourne, Parkville, Victoria, Australia.

Raznitsin, A. P. 1980. Origin and evolution of hymenopterous insects. [In Russian.] Tr. Paleontol. Inst. Akad. Nauk SSSR 174:1-190.

Reid, M. S., D. W. Fujino, N. E. Hoffman, and C. S. Whitehead. 1984. 1-Aminocyclopropane-1carboxylic acid (ACC)-the transmitted stimulus in pollinated flowers? J. Plant Growth Regul. 3:189-196. 
Retallack, G., and D. L. Dilcher. 1981. Early angiosperm reproduction: Prisca reynoldsii gen. et sp. nov, from mid-Cretaceous coastal deposits in Kansas, USA. Palaeontogr. Abt. B, Palaeophytol. 179:103-137.

Rhodendorf, B. B., and A. P. Raznitsin. 1980. The historical development of the class Insecta. [In Russian.] Tr. Paleontol. Inst. Akad. Nauk SSSR 175:1-268.

Schweitzer, H. J. 1977. Die Räto-Jurassischen Floren des Iran und Afghanistans: 4, Die Rätische Zwitterblüte Irania hermaphroditica nov. spec. und ihre Bedeutung für die Phylogenie der Angiospermen. Palaeontogr. Abt. B, Palaeophytol. 161:98-145.

Shoulders, E. 1968. Fertilization increases longleaf and slash pine flower and cone crops in Louisiana. J. For. 66:193-197.

Smoot, E. L., and T. N. Taylor. 1985. Ovules from the Permian of Antarctica. [Abstr.] Am. J. Bot. 72:900-901.

Stewart, W. N. 1983. Paleobotany and the evolution of plants. Cambridge University Press, New York.

Strong, D. R., J. H. Lawton, and R. Southwood. 1984. Insects on plants: community patterns and mechanisms. Harvard University Press, Cambridge, Mass.

Surange, K. R., and S. Chandra. 1975. Morphology of the gymnospermous fructifications of the Glossopteris flora and their relationships. Palaeontogr. Abt. B, Palaeophytol. 149:153-180.

Taylor, T. N., and S. Archangelsky. 1985. The Cretaceous pteridosperms Ruflorinia and Ktalenia and implications on cupule and carpel evolution. Am. J. Bot. 72:1842-1853.

Terreros, J. R., G. Chavarro, and F. O. Rojas. 1982. Determinación de dos genotipos de incompatibilidad o compatibilidad en varios cultivares de Cacao (Theobroma cacao L.). Rev. Inst. Colomb. Agropecu. 17:93-99.

Thien, L. B., D. A. White, and L. Y. Yatsu. 1983. The reproductive biology of a relict-Illicium floridanum Ellis. Am. J. Bot. 70:719-727.

Thomas, H. H. 1925. The Caytoniales, a new group of angiospermous plants from the Jurassic rocks of Yorkshire. Philos. Trans. R. Soc. Lond. B, Biol. Sci. 213:299-363.

1933. On some pteridospermous plants from the Mesozoic rocks of South Africa. Philos. Trans. R. Soc. Lond. B, Biol. Sci. 222:193-265.

1955. Mesozoic pteridosperms. Phytomorphology 5:177-185.

Wenger, K. F. 1953. The effect of fertilization and injury on the cone and seed production of loblolly pine seed trees. J. For. 51:570-573.

Whitehouse, H. L. K. 1950. Multiple-allelomorph incompatibility of pollen and style in the evolution of angiosperms. Ann. Bot. (Lond.) 14:199-216.

Wiemken-Gehrig, V., A. Wiemken, and P. Matile. 1974. Mobilisation von Zellwandstoffen in der welkenden Blüte Ipomoea tricolor Cav. Planta 115:297-307.

Willson, M. F. 1979. Sexual selection in plants. Am. Nat. 113:777-790.

Willson, M. F., and N. Burley. 1983. Mate choice in plants: tactics, mechanisms and consequences. Princeton University Press, Princeton, N.J.

Zavada, M. S. 1984a. The relation between pollen exine sculpturing and self-incompatibility mechanisms. Plant Syst. Evol. 147:63-78.

1984b. Angiosperm origins and evolution based on dispersed fossil pollen ultrastructure. Ann. Mo. Bot. Gard. 71:444-463.

Zavada, M. S., and W. L. Crepet. 1986. Pollen wall structure of Caytonanthus arberi. Plant Syst. Evol. (in press).

Zavada, M. S., and T. N. Taylor. 1986. Pollen morphology of Lactoridaceae. Plant Syst. Evol. (in press). 